\title{
Local Food and Beverages as a Tool for Regional Tourism Development: Case Study
}

\section{Iveta Hamarneh*}

Department of Tourism, University College of Business in Prague, Czech Republic

*Corresponding Author: Iveta Hamarneh, Department of Tourism, University College of Business in Prague, Czech Republic.

DOI: 10.31080/ASNH.2020.04.0729
Received: June 27, 2020

Published: July 16, 2020

(C) All rights are reserved by Iveta Hamarneh.

\section{Abstract}

The aim of the paper is to introduce and evaluate the Ústí nad Labem region for food tourism. The Region belongs to the less visited areas in the Czech Republic although Region offers suitable conditions for tourism development. We can assume that the interest in local food in frame of food tourism in the Region can subsequently increase overall visitation of Ústín ad Labem Region. Methods which were used for completing the paper included literature review, content analysis of documents and case study. Keywords: Czech Republic; Gastronomic Tourism; Local Food; Potential of Tourism; Ústí nad Labem Region

\section{Introduction}

Local food is essential place-marker in tourism promotion. The climatic condition, culture, and history of the region shape the food's character. Gastronomy is often said to be a sub-sector of cultural or heritage tourism for this reason. This link between location and gastronomy has been used in several ways in tourism, including promotional efforts based on distinctive or "typical" regional or national foods.

Food and gastronomy have a particularly important role in the development of tourism services, since it often comprises $30 \%$ or more of tourist expenditure, and this money is regularly spent directly with local businesses [1]. Tourists are increasingly seeking local, authentic, and novel experiences linked intrinsically to the places they visit.

\section{Literature Review}

Du Rand, Heath and Alberts [2] outline ways in which local food may directly or indirectly contribute to local sustainable development (See figure 1). Contributions include enhancing destination attractiveness, empowerment through local job creation and entrepreneurship, regional brand identification, authentic presentation of the local culture, stimulation of agricultural activity, and generation of pride in the region.

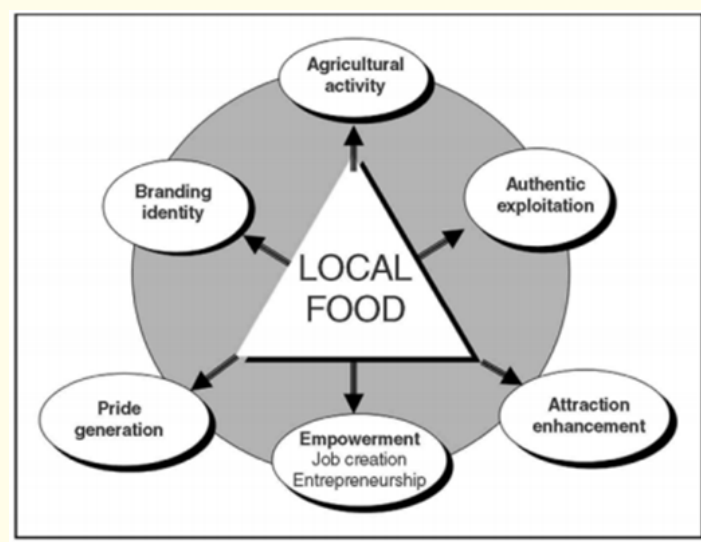

Figure 1: The contribution of local food to sustainable development within a destination.

Source: Adapted from [2].

Tourism and local food have the potential for collaboration in a symbiotic relationship [3]. Food is usually seen as a symbol of local a regional distinctiveness, and when tourists choose local food and beverage, they also taste "ingredients" of the visited area's local character [4]. In many tourism regions, local gastronomy is seen as a significant component of the local heritage and regional food cul- 
ture has been described as a competitive advantage for local and regional produce and improve the quality of tourists' experience and add a local uniqueness [5].

The impacts and benefits of gastronomic tourism for regions can include an increased demand for food-related products, the building of brand loyalty, marketing intelligence for producers and suppliers, educational opportunities for visitors and residents, regional and local employment creation, extension of the tourist's stay in an area, wider distribution of spending and the protection of intellectual property [6].

\section{Case Study and Discussion}

The Ústí nad Labem region belongs to the less visited parts of the Czech Republic [7], although the Region has great potential for tourism development. Unfortunately, this potential is not currently enough used.

The Ústí nad Labem Region is noted for relatively high unemployment and low socio-economic status compared with other Czech Republic's regions. Tourism and in particular food tourism can be a means for the better economic development of the Region. The future growth of the food tourism can be supported by the existing conditions for it (attractive location, agriculture land, production of hops and vegetables, growing grapes, rural areas, etc).

The Ústí nad Labem region has an attractive location between Prague and Germany. The region is situated in the northwest of the Czech Republic along its northern border with Germany. Other neighbors include the Liberec Region in the northeast, the Karlovy Vary and Pilsen Regions in the west, and the Central Bohemian Region in the southeast. The region's area of 5,339 $\mathrm{km}^{2}$ accounts almost 7\% of the Czech Republic's total area. More than $50 \%$ of the Region is covered with agricultural land, $30 \%$ of forests, while water areas make up $2 \%$ of the territory [7].

The zone along the German borders is dominated by the Ore Mountains the Sandstone Rocks of Labe and the Lužice Mountains. The Ore Mountains are geologically quite old, and they are formed of volcanic rocks or Paleozoic schist. In opposite, the south-eastern part of the region is formed by the plains that originate from $\mathrm{Me}$ sozoic era (Czech Cretaceous Formation). The Bohemian Central Uplands and the Říp Mountain are both located in this area. The
Bohemian Central Uplands (with its highest peak Milešovka) originated from volcanic activity in the Tertiary and has a unique scenery with many contrasts and charming isolated spots. The highest point of the Region (1225m) is situated on the hillside of Klínovec, which is the highest peak of the Ore Mountains. The lowest point of the region (and at the same time of the Czech Republic) is the cover of the Elbe River at Hřensko with $115 \mathrm{~m}$ above the sea level. Part of the territory of the Region is covered by the Bohemian Switzerland, national park with the area of 7,900 hectares that was founded in 2000.

Geographically the Region is very heterogeneous, with considerable variations in natural conditions, economic structure, a density of settlement and environmental conditions. Historically, the economic importance of the Region is based on its raw materials, especially large deposits of brown coal. There are also other essential raw materials in the Region, for example, quality glass and foundry sands and building stone [7].

Four different areas are found in the region:

- Areas with highly developed industrial production concentrated in the foothills of the Ore Mountains. Power engineering is significant here as well as coal mining, mechanical engineering, and chemical and grass industries.

- Areas around Litoměřice and Louny with agriculture mainly hops and vegetable production. In the field around the river Labe and the river Ohře, there are fruit-growing regions called the Garden of Bohemia. Grapes grown in the Litoměřice area have an excellent reputation. During recent years, the area along Most has shifted a known wine-growing region, in which wine is produced mainly on lands that were reclaimed after brown coal mining.

- The Ore Mountains area is a mountain range with sparse population and limited economic activities.

- The area around Děčín is dominated neither by industry nor by agriculture but has attractive localities for tourism.

And how can we evaluate the tourism potential in the Region? Due to its rich history of settlement, the Ústí nad Labem Region boasts of a vast number of historic buildings and monuments. The best known is Romanesque rotunda on the Ríp Mountain, Gothic church 
in Most, the baroque castle in Duchcov, the monastery in Osek and Doksany and chateaux Ploskovice and Libochovice. Litoměřice, Úštěk, and Terezín were designated urban conservation areas, and center of Roudnice nad Labem is a protection area.

Some of the villages in the Litoměřice area were chosen for rural conservation zones. Also, there are painting collections of great worth in the Litoměřice picture gallery. On Litoměřice exhibition grounds various types of actions take place during the year. Very well-known is the Garden of Bohemia sales exhibition focused on growing of fruits and vegetables or a fair specialized on domestic equipment and construction goods called

My house, my castle. To name some of the beauties of nature, the best known is the national park the Bohemian Switzerland with its famous the Pravčice Gate, lovely Gate to Bohemia (Porta Bohemica) along the river Labe and many others.

For those who like sports, the Ústí nad Labem region also has something to offer. There is a modern racecourse, motor-racing circuit, golf area, all that in the town of Most. The Ore Mountains and also the Lužice Mountains offer excellent conditions for skiing.

Rural landscapes and mountain scenery are typical for the Ústí nad Labem region regarding functionally-spacial land use. Urbanized areas occupy more than $15 \%$ of the territory of the region (See figure 2). There are exciting and tourist uncongested mountain areas, cultural-historical monuments, sustainable hiking and biking terrain, natural reservoirs, and artificial water bodies in the Ústí nad Labem region. There are sites with great summer and winter hiking conditions. The region has excellent conditions for the development of tourism but is not too attractive for tourists.

In the Czech Republic, we currently register a total of 41160 food and beverages facilities. From a regional perspective, the food and beverages facilities are distributed unevenly. As figure 3 shows, the dominant position has Prague (14\% of all facilities), Central Bohemian Region (12\%), South Moravian Region and Moravian-Silesian Region (10\%). The Ústí nad Labem region has 3110 food and beverages facilities $(7,6 \%)$. The highest price level we register in Prague, while the lowest price level is in the Ústí nad Labem Region and Vysočina Region.

Events related to food/beverages in the Ústí nad Labem region are clearly presented in figure 4 . Food festivals, traditional mar-

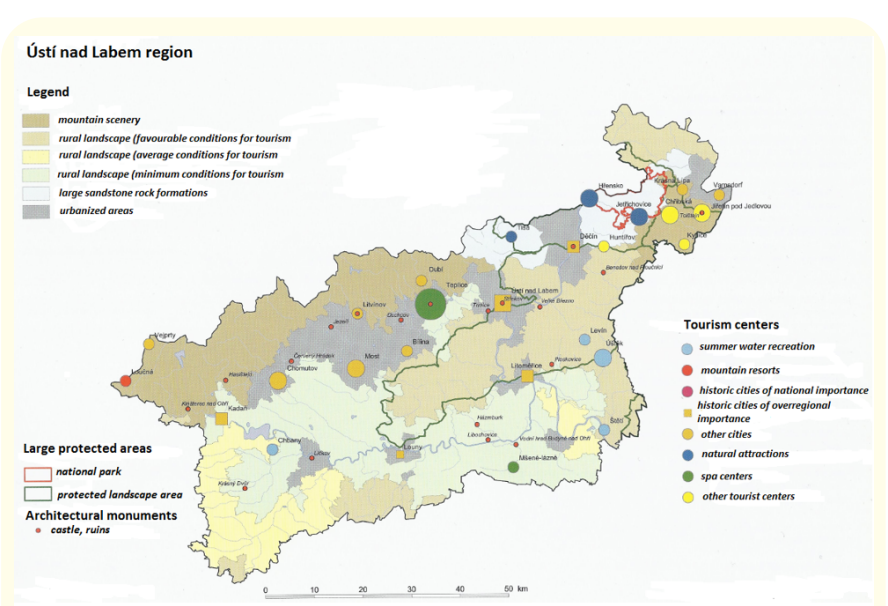

Figure 2: The potential of tourism in the Ústí nad Labem region. Source: Adapted by [8].

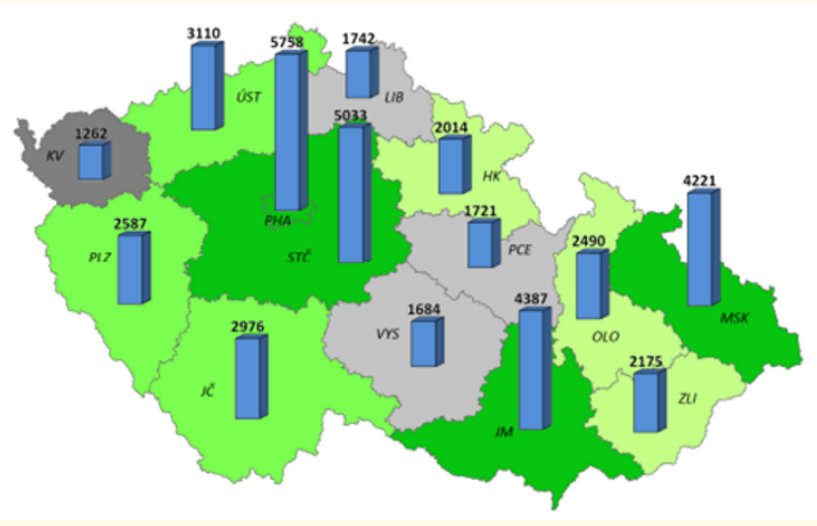

Figure 3: Number of food and beverages facilities by region in 2014 . Source: Adapted by [9].

kets, and farmers' markets which offer a delicious assortment of food, beverages and quality organic products, are growing in popularity. For domestic and foreign visitors, these places are an ideal opportunity to get familiarized with honest and genuine Czech cuisine. These events operate in different parts of the Czech Republic, including the Ústí nad Labem Region.

For small and medium farmers, producers and growers predominantly from the region, there is frequently an almost insuperable problem of getting their products to the formal distribution network of the major retail chains. The method of finding custom- 


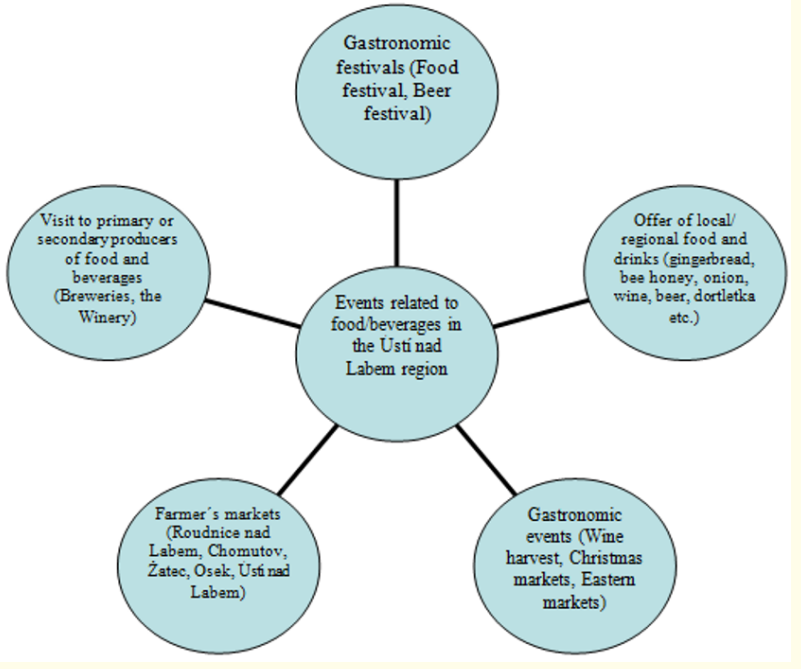

Figure 4: Events related to food/beverages in the Ústí nad Labem region.

Source: Author.

ers while avoiding hypermarkets are supermarkets and private bio-stores. The demand for them is rising because Czech and also foreign consumers are starting to realize how significant it is to have a choice of quality local food, which doesn't use unnecessary preservatives, substitutes, harmful E's and other dangerous chemicals. These shops can be seen in almost every big city in the Czech Republic, including the Ústí nad Labem Region.

\section{Conclusion}

The Ústí nad Labem region is noted for relatively high unemployment and low socio-economic status compared with other Czech Republic regions. Tourism and also food tourism is looked to as having the potential to provide jobs and income.

Local drinks and regional food contribute to local sustainable development through enhancing destination attractiveness, stimulation of agricultural activity and local job creation and entrepreneurship. The interest in gastronomic tourism can increase overall visitation of the Ústí nad Labem region, increase employment, support local farm production and finally, can improve the living standards of residents.
The Ústí nad Labem region has very good conditions for the future development of food and gastronomic tourism. We can mention especially attractive location, agriculture land, rural areas, existing of local farmers and winery, production of hops and vegetables, growing grapes, organizing the events related to food and beverages, etc.

\section{Bibliography}

1. OECD. "Food and the Tourism Experience: The OECD - Korea Workshop". OECD Studies on Tourism. OECD Publishing (2012).

2. Du Rand G., et al. "Role of Local and Regional Food in Destination Marketing: A South African Situation Analysis" (2003).

3. Hjalanger AM and Richards G. "Tourism and Gastronomy". London: Routledge (2002).

4. Bessière J. "Local development and heritage: traditional food and cuisine as tourist attractions in rural areas". Sociologia Ruralis 38.1 (1998): 21-34.

5. Yi-Chin L., et al. "Food as a form of Destination Identity: A Tourism Destination Brand Perspective". Tourism and Hospitality Research 11.1 (2011): 30-48.

6. Smith., et al. "Key Concepts in Tourist Studies". SAGE Publications Ltd (2011).

7. “Statistical Yearbook of the Ústecký Region - 2019” (2019).

8. Vystoupil J and Kol. "Atlas cestovního ruchu České republiky". Praha: Ministerstvo pro mísní rozvoj ČR, (2006).

9. Ministerstvo pro místní rozvoj ČR: "Podpora regionů a cestovní ruch". Konference ke statistickým projektům odboru cestovního ruchu ke zkvalitnění statistických informací v oblasti cestovního ruchu: Monitoring stravovacích zařízení - prezentace hlavních výsledků.

\section{Assets from publication with us}

- Prompt Acknowledgement after receiving the article

- Thorough Double blinded peer review

- Rapid Publication

- Issue of Publication Certificate

- High visibility of your Published work

Website: www.actascientific.com/

Submit Article: www.actascientific.com/submission.php

Email us: editor@actascientific.com

Contact us: +919182824667 